\section{Characteristics and Factors Associated with Adverse Cutaneous Drug Reactions Caused by Traditional, Complementary and Conventional Medicine in Malaysia}

\author{
NOR HAZLIN T${ }^{1}$, LEELAVATHI M $^{2}$, ZUHRA H², ADAWIYAH J ${ }^{3}$, \\ DAWN AA ${ }^{4}$
}

${ }^{1}$ Klinik Kesihatan Tengkera, Jalan Tengkera, 75200 Melaka

${ }^{2}$ Department of Family Medicine, ${ }^{3}$ Dermatology Unit, Department of Medicine, Faculty of Medicine, Universiti Kebangsaan Malaysia Medical Centre, Jalan Yaacob Latif, Bandar

Tun Razak, 56000 Cheras, Kuala Lumpur, Malaysia.

${ }^{4}$ Dermatology Department, Hospital Kuala Lumpur, Jalan Pahang, 50586 Kuala Lumpur

\begin{abstract}
ABSTRAK
Ubatan tradisional boleh menyebabkan kesan sampingan pada kulit. Tujuan kajian ini adalah untuk mengkaji ciri-ciri kesan sampingan pada kulit yang disebabkan oleh ubatan tradisional dan dibandingkan ubatan konvensional. Satu kajian retrospektif telah dijalankan terhadap 134 kes yang dikenalpasti di Klinik Dermatologi di hospital tertiari Kuala Lumpur. Kebanyakan kes (82.1\%) adalah disebabkan oleh ubat-ubatan konvensional manakala $17.9 \%$ adalah disebabkan oleh ubatan tradisional. Kesan sampingan ubatan tradisional pada kulit yang paling lazim adalah Exfoliative Dermatitis (ED) dan Acute Generalized Exanthematous Pustulosis (AGEP) (kedua-duanya 16.7\%) manakala ruam makulopapular adalah reaksi yang paling lazim bagi ubatan konvensional (25.5\%). Jangkamasa mulanya reaksi kesan sampingan ubatan pada kulit disebabkan oleh ubatan tradisional adalah hampir 4 minggu (60.2\%) manakala ubat konvensional adalah lebih awal (1 hingga 6 hari, 65.4\%) (p<0.05). Kemungkinan munculnya kesan sampingan ubatan yang tertunggak (4 minggu) adalah 14 kali lebih kerap dengan ubatan tradisional berbanding dengan ubat konvensional ( $p<0.05)$. Kajian ini menunjukkan bahawa ED dan AGEP adalah kesan sampingan kulit yang paling lazim disebabkan oleh ubat tradisional manakala ruam makulopapular lebih kerap berlaku dengan ubatan konvensional. Walau bagaimanapun, kebanyakan kesan sampingan ini adalah pada tahap sederhana. Oleh sebab kesan sampingan ubatan tradisional sering muncul selepas jangkamasa yang lama, riwayat penggunaan ubatan tradisional seharusnya didapatkan secara rutin bagi pesakit yang mempunyai masalah kulit
\end{abstract}

Address for correspondence and reprint requests: Associate Professor Dr. Leelavathi Muthupalaniappen. Department of Family Medicine, Faculty of Medicine, Universiti Kebangsaan Malaysia Medical Centre, Jalan Yaacob Latif, Bandar Tun Razak, 56000 Cheras, Kuala Lumpur, Malaysia. Tel: +603-91459475 Email: drleelaraj@gmail.com 
walaupun ubatan ini telah lama digunakan. Semua kes yang disyaki mempunyai kesan sampingan pada kulit disebabkan oleh ubatan tradisional haruslah dilaporkan kepada Malaysian Adverse Drug Reactions Advisory Committee (MADRAC) supaya ubatan tradisional dapat dipantau dari semasa ke semasa untuk menjamin keselamatan pengguna.

Kata kunci: kesan sampingan, reaksi ubat, ubat, tradisional

\section{ABSTRACT}

Traditional and Complimentary Medicines (TCMs) can potentially cause Adverse Cutaneous Drug Reactions (ACDRs). The aim of this study was to describe the characteristics of ACDRs due to TCMs and compare with those due to conventional medicine. This was a retrospective study with 134 cases being diagnosed with ACDR at the Dermatology Clinic of a tertiary hospital in Kuala Lumpur. Most (82.1\%) ACDRs were caused by conventional drugs, while $17.9 \%$ were due to TCMs. Majority (70-75\%) of the ACDRs were of mild to moderate severity. The most common ACDR to TCM was Exfoliative Dermatitis (ED) and Acute Generalized Exanthematous Pustulosis (AGEP) (both 16.7\%) while maculopapular rash was the most common reaction for conventional medications $(25.5 \%)$. The onset of adverse reaction to TCM was about 4 weeks (60.2\%) while reactions due to conventional medication was earlier ( 1 to 6 days, $65.4 \% ; p<0.05$ ). The odds of developing delayed ACDR was 14 times more with TCM compared to conventional medicine $(p<0.05)$. This study showed that ED and AGEP were the most common ACDR manifestations of TCM while macuplopapular rash was the most common manifestation of conventional medications. However, most of these reactions were of mild to moderate severity. ACDR due to TCM may manifest long after the initiation of these products and hence its use should be routinely inquired when patients present with skin problems. All suspected cases of ADRs to TCM should be reported to the Malaysian Adverse Drug Reactions Advisory Committee (MADRAC) for continuous pharmacovigilance of these products.

Keywords: drug eruption, medicine, skin, traditional

\section{INTRODUCTION}

Traditional and complementary medicine (TCM) is popular worldwide, especially in Asia, where almost half of the population report its use either as a supplement or for illness treatment.
(Relton et al. 2017) In Malaysia, the prevalence of TCM consumption is about $70-80.2 \%$ (Kew et al. 2015; Johny et al. 2017). TCM may be perceived as harmless as it is obtained from naturally existing compounds, compared to conventional drugs which 
are manufactured from chemicals. Adverse Drug Reaction (ADR) due to TCM were reported to occur with both oral consumed and topical use (Kim et al. 2013; Leelavathi et al. 2016). Although TCMs are natural products, existing reports on ADRs suggests a need to increase pharmacovigilance to ensure the safety and efficacy of these products (Kiguba et al. 2016; Kim et al. 2013).

Numerous published data is available on Adverse Cutaneous Drug Reactions (ACDRs) due to conventional medicine such as anticonvulsants, antibiotics and NSAIDs (Mokhtari et al. 2014; Dua et al. 2016). However, data regarding ACDR to TCM is still lacking. This information may not have been captured as consumers may not be aware or have dismissed the possibility of TCM causing adverse reactions as these products are natural in origin. The knowledge of the spectrum of ACDRs due to TCM is essential as this will enable physicians to have a higher index of suspicion and make a clinical diagnosis based on history and the morphology of lesions. Hence, the objective of this study was to determine the prevalence, severity, characteristics factors associated with ACDRs due to TCMs and compared with conventional medicine. It is expected that the findings from this study will create awareness, help differentiate ACDRs due to TCMs and conventional medicine and provide data for future research and development.

\section{MATERIALS AND METHODS}

A retrospective cross-sectional study was conducted at the dermatology facility of a tertiary hospital in Kuala Lumpur Hospital form $1^{\text {st }}$ January 2009 to $31^{\text {st }}$ December 2010. Sample size was calculated using Kish formula. Sample size $=1.96^{2} \times\left(0.447(1-0.447) 0.1^{2}=96\right.$. An additional $30 \%$ was added taking into consideration possible incomplete documentation or missing files. The required sample size was 125 . Since total number of ACDR cases registered in the computer database was 141, all cases (universal sampling) were included in this study. Case notes were traced and reviewed by the researcher. All ACDR cases secondary to oral consumption of conventional medicine and TCM were selected from the database and the required information was extracted from the patient's case notes. Details such as patient's demography, reason for TCM use, type of cutaneous manifestation and the onset of lesions were entered to the data collection form. The diagnosis of ACDR was established based on the documentation made in the case notes by the attending dermatologist at the point of consultation based on Naranjo algorithm (Naranjo et al. 1981). Cases which were diagnosed as definite, probable or possible ACDR, were selected. Patients with missing case notes or incomplete documentation in the case notes, were excluded. This study was approved by the Ministry of Health Medical Research Ethics Committee [NMRR-10-752-6921] and Universiti Kebangsaan Malaysia Ethics Committee [FF-374-2010].

The severity of the ACDR was classified as mild, moderate and severe reactions. Steven Johnson 
Syndrome (SJS), Toxic epidermal Necrolysis (TEN), Drug Rash with Eosinophilia and Systemic Symptoms (DRESS) and Exfoliative Dermatitis (ED) were considered as severe ACDRs. Moderate ACDRs were those who required hospital admission, received any change in treatment or received specific interventional treatment (Palmer et al. 2003). Those who did not require hospitalization or any specific therapy were considered as mild ACDRs.

Earlier studies had established that older adults were more susceptible to adverse reactions. Some had categorized older adults as those above 50 while others as above 60 years of age. For the purpose of this study, the age group was categorised as below and above 60 years of age as 60 years and above was considered as old age in Malaysia (warga emas).

Since an accepted classification for the duration of onset of adverse cutaneous drug reaction was not available, an arbitrary time frame based on the different types of established adverse reactions (Type I to IV) was used to describe the variable time taken from oral consumption of medication to the appearance cutaneous lesions (Riedl et al. 2003). This was however is not intended to be used as a classification but merely for description purposes.

Data analysis was done using the statistical package for the Social Sciences (SPSS) for windows version 17.0. Student's t-test, Chi-square and logistic regression tests were used and $p$-value of less than 0.05 was considered as significant.

\section{RESULTS}

A total of 69,849 patients were seen at the Dermatology Clinic during the study period. The number of ACDR identified from the computer data base was 141 . Out of this, 7 were excluded (3 ACDR were due to topical application, 2 case notes were missing and another 2 cases had overlap of information). The overall prevalence of ACDR was $0.2 \% \quad(n=134)$. Among these, $82.1 \%$ $(n=110)$ were due to conventional medicine while $17.9 \%(n=24)$ were due to TCM. These reactions commonly occurred among those younger than 60 years $(70-75 \%, n=96)$. Both females and males were equally affected (1.2:1). Majority of those affected by ACDRs to TCM and conventional medicine belonged to the Malay ethnic group (Table 1). The most common reason for consuming TCM was to enhance general well-being $(37.5 \%, n=9)$ (Table 2).

The most common manifestations of ACDR to TCM was exfoliative dermatitis and Acute Generalized Exanthematous Pustulosis (AGEP; both $16.7 \%, n=4)$, while ACDRs to conventional medication commonly presented with maculopapular rash $(25.5 \%, n=28)$. Majority of ACDR to TCMs were delayed, with reactions developing up to 4 weeks after consumption $(62.0 \%, n=13)$ while ACDR due to conventional medications commonly presented earlier, within 1 to 6 days $(65.4 \%, n=70)$. ACDRs to TCMs consists mostly of mild (33.3\%, $\mathrm{n}=8)$ and moderate $(37.5 \%, \mathrm{n}=9)$ reactions while only a small percentage presented with severe reactions 
Table 1: Characteristic of patients with ACDR to TCM and conventional medicine

\begin{tabular}{lcc}
\hline \multicolumn{1}{c}{ Characteristics } & $\begin{array}{c}\text { ACDR to TCM } \\
\%(\mathbf{n})\end{array}$ & $\begin{array}{c}\text { ACDR to conventional drugs } \\
\%(\mathbf{n})\end{array}$ \\
\hline Age, mean $( \pm \mathrm{SD})$ & $50.0(+16.6)$ & $46.4(+17.7)$ \\
Age groups & & $70.9(78)$ \\
$\leq 59$ years & $75.0(18)$ & $29.1(32)$ \\
$\geq 60$ & $25.0(6)$ & \\
Gender & & $47.3(52)$ \\
Female & $54.2(13)$ & $52.7(58)$ \\
Male & $45.8(11)$ & \\
Ethnicity & & $61.8(68)$ \\
Malay & $62.5(15)$ & $19.1(21)$ \\
Chinese & $20.8(5)$ & $11.8(13)$ \\
Indian & $8.3(2)$ & $7.3(8)$ \\
Others & $8.3(2)$ & \\
\hline
\end{tabular}

(29.2\%, $\mathrm{n}=7)$ while most ACDRs due to conventional medications were of moderate severity $52.7 \% \quad(n=58)$. Table 3. TCM more commonly caused delayed onset (4 weeks) of ACDRs compared to conventional medicine $(p<0.05)$ (Table 4). TCM also had 14 times the odds of manifesting beyond 4 weeks compared to conventional medicine (Table 5).

\section{DISCUSSION}

TCM has been used for many generations for diseases treatment and for maintaining good health. Issues regarding its efficacy and safety are of

Table 2: Common reasons for TCM use

\begin{tabular}{lc}
\hline \multicolumn{1}{c}{ Reasons for TCM use } & \% (n) \\
\hline Well being & $37.5(9)$ \\
Symptomatic relief & $20.8(5)$ \\
Not documented & $20.8(5)$ \\
Supplement & $12.5(3)$ \\
Chronic illness & $8.3(2)$ \\
\hline
\end{tabular}

increasing concern as these products are usually marketed as supplements, hence exempted from regular scrutiny as opposed to conventional medicine. Consumers may regard TCMs as supplements and hence may not declare their usage. One study found that majority TCM users did not declare its usage to their physicians (Kew et al. 2015; Kim et al. 2013). Patients may not report ADRs to due to a false perception that TCMs are natural extracts, hence free from adverse reactions. Hence, there is a possibility that ADRs due to TCM are underreported. Patients should be regularly inquired into the use of over the counter (OTC) drug or supplements, evaluated for any adverse reactions in the past and advised to report any reactions promptly.

The current study showed a high prevalence of ACDR to TCM and it was the second most common cause after antibiotics. The details of the data from this cohort pertaining to ACDR secondary to conventional medicine 
Table 3: Clinical characteristics of ACDR to TCM and conventional medicine

\begin{tabular}{lcc}
\hline \multicolumn{1}{c}{ Characteristics } & $\begin{array}{c}\text { ACDR to TCM } \\
\%(\mathbf{n})\end{array}$ & $\begin{array}{c}\text { ACDR to conventional drugs } \\
\%(\mathbf{n})\end{array}$ \\
\hline Cutaneous manifestations & & $6.4(7)$ \\
Exfoliative dermatitis & $16.7(4)$ & $0.9(1)$ \\
AGEP & $16.7(4)$ & $9.1(10)$ \\
SJS & $12.5(3)$ & $1.8(2)$ \\
Vasculitis & $12.5(3)$ & $25.5(28)$ \\
Maculopapular rash & $8.3(2)$ & $6.4(7)$ \\
Urticaria & $4.2(1)$ & $5.5(6)$ \\
Erythema multiforme & $4.2(1)$ & $10.9(12)$ \\
Fixed drug eruption & - & $10.0(11)$ \\
Photodermatitis & - & $5.5(6)$ \\
TEN & - & $5.5(6)$ \\
Angioedema & - & $4.5(5)$ \\
DRESS & - & - \\
Bullous phempigoid & $8.3(2)$ & $8.2(9)$ \\
Others & $16.7(4)$ & \\
Onset & & $65.4(70)$ \\
1 to 6 days & $19.0(4)$ & $18.7(20)$ \\
1 to 4weeks & $19.0(4)$ & $15.9(17)$ \\
$>4$ weeks & $62.0(13)$ & $22.7(25)$ \\
Severity & & $52.7(58)$ \\
Mild & $33.3(8)$ & $24.6(27)$ \\
Moderate & $37.5(9)$ & \\
Severe & $29.2(7)$ & \\
\hline & & \\
\hline
\end{tabular}

have been described elsewhere (Talib et al. 2015). Earlier studies also found that herbal medicines were a common cause for ACDR causing reactions similar to those with conventional medicine (Sudershan et al. 2014; Li \& Ma 2006). The annual report of the Malaysian Adverse Drug Reactions Advisory Committee (MADRAC) shows an increasing trend of ADR to TCM. Hence, physicians should be aware of the potential adverse effects associated with TCM, giving special emphasis to a detailed drug history during consultation. (National Center for Adverse Drug Reaction Monitoring 2015).

Majority of those affected by ACDRs to TCM and conventional medicine were from the Malay ethnic group. This reflects the local ethnic distribution closely as the majority in Malaysia belong to the Malay ethnic community followed by the Chinese, Indians and others. ACDR to TCM in this study commonly occurred among those younger than 60 years of age, which is almost similar to 
Table 4: Association between ACDR to TCM and conventional medicine with demographic factors, onset \& severity.

\begin{tabular}{lcccc}
\hline $\begin{array}{c}\text { Demographic } \\
\text { variables }\end{array}$ & $\begin{array}{c}\text { TCM } \\
\%(\mathbf{n})\end{array}$ & $\begin{array}{c}\text { Conventional } \\
\text { medicine } \%(\mathbf{n})\end{array}$ & Test & p value \\
\hline Mean age (years) & $50.0 \pm 16.6$ & $46.4 \pm 17.7$ & $\begin{array}{c}\text { Independent } \\
\text { t-test } \\
\mathrm{t}=0.924\end{array}$ & 0.357
\end{tabular}

Age subgroup

\begin{tabular}{|c|c|c|c|c|}
\hline$\leq 59$ years & $75.0(18)$ & $70.9(78)$ & & \\
\hline$\geq 60$ years & $25.0 \quad(6)$ & 29.1(32) & $x^{2}=0.1623$ & 0.687 \\
\hline \multicolumn{5}{|l|}{ Gender } \\
\hline Female & $54.2(13)$ & $47.3(52)$ & & \\
\hline Male & $45.8(11)$ & $52.7(58)$ & $x^{2}=0.375$ & 0.540 \\
\hline \multicolumn{5}{|l|}{ Ethnicity } \\
\hline Malay & 62.5 (15) & $61.8(68)$ & & \\
\hline Non-Malay & $37.5(9)$ & $38.2(42)$ & $x^{2}=0.004$ & 0.950 \\
\hline \multicolumn{5}{|l|}{ Onset } \\
\hline 1 to 6 days & $19.0(4)$ & $65.4(70)$ & & \\
\hline 1 to 4 weeks & $19.0(4)$ & $18.7(20)$ & $x^{2}=22.391$ & $<0.05$ \\
\hline$>4$ weeks & $62.0(13)$ & $15.9(17)$ & & \\
\hline \multicolumn{5}{|l|}{ Severity } \\
\hline $\begin{array}{l}\text { Non-severe (mild \& } \\
\text { moderate) }\end{array}$ & $70.8(17)$ & $75.5(83)$ & & \\
\hline Severe & $29.2(7)$ & $24.5(27)$ & $x^{2}=0.222$ & 0.637 \\
\hline
\end{tabular}

ACDR to conventional medications. Although ADR generally occurs more commonly among older adults, this was not apparent in our study (Nine Reasons Older Adults Are More Likely to Have Adverse Drug Reactions). It is a general assumption is that, the older generation may prefer TCM products compared to conventional medicine. However, the choice of medicine may be influenced by many factors such as personal, cultural believes and access to medication. Other factors which need to be considered are pre-existing co-morbidities, poly-pharmacy, and nutritional status which may have a

Table 5: Onset of ACDR manifestation in TCM and conventional medicine (regression analysis)

\begin{tabular}{lccc}
\hline \multicolumn{1}{c}{ Characteristics } & Crude OR* & Adjusted OR+ $(95 \% \mathrm{Cl})$ & p Value $\neq$ \\
\hline Onset & & & \\
1 to 6 days & 1 & 1 & - \\
1 to 4weeks & $3.500(0.803,15.275)$ & $3.285(0.733,14.727)$ & 0.120 \\
$>4$ weeks & $13.382(3.874,46.228)$ & $14.016(3.791,51.820)$ & $<0.001$ \\
\hline
\end{tabular}

* OR computed by simple logistic regression; +OR computed by multiple logistic regressions controlling for all variables listed; ₹ Likelihood ratio test. 
role in influencing ADR (Caamano et al. 2005).

Our study did not show any gender predilection for developing ACDRs. Earlier studies have showed that females in general, are more likely to consume TCM compared to males (Shih et al. 2012; Zhang et al. 2015). The most common reason for consumption of TCM in this study was to maintain general well-being or as a health supplement, which is similar to an earlier local study (Kew et al. 2015). The unnecessary consumption of TCMs and resultant ACRDs could be avoided if there was increased awareness of healthy life style concept rather than resorting to supplements.

Majority of ACDRs secondary to TCM and conventional medicine in this study are of mild and moderate severity while only a few were in the severe category. These findings are similar to other studies (Sudershan et al. 2012; Li \& Ma 2006). ACDR due to TCM may also involve other systems besides the skin (Zeng \& Jiang 2010). There are several ways that TCM products may cause adverse reactions. It may be due to its inherent toxic content, unintentional or intentional substitution, adulteration with prescription drugs or due to environmental contamination (Ching et al. 2018).

The most common manifestations of ACDR to TCM in this study were exfoliative dermatitis and AGEP, while maculopapular and Fixed Drug Eruptions (FDEs) were more common with conventional drugs. Other common ACDR manifestations of TCM which have been reported include TEN, exfoliative dermatitis, erythema multiforme, pemphigus, hemorrhagic and urticarial lesion (Sudershan et al. 2012; Zeng \& Jiang 2010). Knowledge of these different cutaneous manifestations may be useful to prompt physicians to consider ACDR as a differential diagnosis in patients presenting primarily with a skin disorder base on the cutaneous morphology.

In this study, ACDRs due to TCMs showed delayed manifestation, up to 4 weeks after consumption compared to conventional medicine. The difference in the onset of reaction, seen in our study population may be explained by the fact that some TCM compounds produce toxic reaction upon accumulation over time. Another earlier study also showed a significant lag between the duration of consumption and appearance of adverse reactions (Palmer et al. 2003). The onset of adverse reactions generally depends on the sensitizing capacity of the drug. Components in TCMs may be composed of small molecules which require prolonged duration to cause sensitization or the allergen may be a reactive metabolite rather than the drug itself (Schnyder \& Pichler 2009; Schrijvers et al. 2015). Some Asian herbal medicines contain heavy metals such as arsenic and mercury which are carcinogeninc (Moreira et al. 2014). Contamination and adulteration of these products may also be responsible for the delayed reaction (Thong \& Tan 2011). Strict enforcement of the existing regulation on TCM is required to ensure quality control to prevent contamination and adulteration of TCM. Information of 
the product clearly describing the content, possible side effects and interactions with other drugs should be made visible on the box or container and made compulsory. This could ensure that TCM products are safe for consumption and efficacious.

Limitations of this study include those related due to the retrospective nature of this study such as incomplete, inconsistent and missing data had to be excluded. Details regarding the specific reasons for using TCM for general well-being also could not be elicited. Underreporting of ADRs may have diluted the actual prevalence of ACDR as mild reactions not warranting referral or admission may not have been captured by this study.

\section{CONCLUSION}

This study found a high prevalence of ACDR manifestations to TCM, commonly presenting as exfoliative dermatitis and AGEP. Physicians need to be aware of the common cutaneous adverse reactions associated with these products as a provisional diagnosis can be made based on morphology of the lesion at the point first contact. ACDR due to TCM is more likely to present beyond 4 weeks of consumption compared to conventional medicine which presents earlier. Hence, the possibility of TCM causing ADR should not be dismissed among patients who have been consuming these products over a long period, as ACDRs may present later.

\section{ACKNOWLEDGEMENT}

The authors would like to thank Dermatology Unit of Hospital Kuala Lumpur and MADRAC for their support during this research. The authors also thank the Director General of Health Malaysia for his permission to publish this article.

\section{REFERENCES}

Caamaño, F., Pedone, C., Zuccalà, G., Carbonin, P. 2005. Socio-demographic factors related to the prevalence of adverse drug reaction at hospital admission in an elderly population. Arch Gerontol Geriatr 40(1): 45-52.

Ching, C.K., Chen, S.P.L., Lee, H.H.C., Lam, Y.H., Ng, S.W., Chen, M.L., Tang, M.H.Y., Chan, S.S.S., Ng, C.W.Y., Cheung, J.W.L., Chan, T.Y.C., Lau, N.K.C., Chong, Y.K., Mak, T.W.L. 2018. Adulteration of proprietary Chinese medicines and health products with undeclared drugs: experience of a tertiary toxicology laboratory in Hong Kong. Br J Clin Pharmacol 84(1): 172-8.

Dua, M., Dua, S., Gehlot, A., Chouhan, O., Singh, A., Tandi, G.P. 2016. An observational study of drug induced cutaneous reactions used in various group of patients. Sch Acad J Pharm 5(3): 76-82.

Johny, A.K., Cheah, W.L., Razitasham, S. 2017. Disclosure of traditional and complementary medicine use and its associated factors to medical doctor in primary care clinics in Kuching Division, Sarawak, Malaysia. Evid Based Complement Alternat Med 2017: 1-10.

Kew, Y.T., Chia, Y.L., Lai, S.M., Chong, K.Y., Ho, X.L., Liew, D.W., Moy, F.M., Selvarajah, S. 2015. Traditional and complementary medicine among study population with cardiovascular risk: use and substitution for conventional medicine in Pahang, Malaysia. Med J Malaysia 70(2): 86-92.

Kiguba, R., Ononge, S., Karamagi, C., Bird, S.M. 2016. Herbal medicine use and linked suspected adverse drug reactions in a prospective cohort of Ugandan inpatients. BMC Complement Altern Med 16: 145.

Kim, J.H., Kwong, E.M., Chung, V.C., Lee, J.C., Wong, T., Goggins, W.B. 2013. Acute adverse events from over-the-counter Chinese herbal medicines: a population-based survey of Hong Kong Chinese. BMC Complement Altern Med 13: 336 .

Leelavathi, M., Teh, R.J., Chellathuray, S. 2016. Contact dermatitis following use of tropical traditional medicine. Med \& Health 11(1): 96 
$-100$.

Li, L.F., Ma, C. 2006. Epidemiological study of severe cutaneous adverse drug reactions in a city district of China. Clin Exp Dermato/ 31(5): 642-7.

Mokhtari, F., Nikyar, Z., Naeini, B.A., Esfahani, A.A., Rahmani, S. 2014. Adverse cutaneous drug reactions: eight year assessment in hospitalized patients. J Res Med Sci 19(8): 720-5.

Moreira, D.L., Teixeira, S.S., Monteiro, M.H.D., De-Oliveira, A.C., Paumgartten F.J.R. 2014. Traditional use and safety of herbal medicines. Revista Brasileira de Farmacognosia 24(2): 24857.

Naranjo, C.A., Busto, U., Sellers, E.M., Sandor, P., Ruiz ,I., Roberts, E.A., Janecek, E., Domecq, C., Greenblatt, D.J. 1981. A method for estimating the probability of adverse drug reactions. Clin Pharmacol Ther 30(2): 239-45.

National Center for Adverse Drug Reaction Monitoring Annual Report. http://npra.moh. gov.my/index.php/recent-updates/publication/ national-centre-for-adverse-drug-reactionmonitoring-annual-report. Updated July 13 2015 [Accessed 18 $8^{\text {th }}$ June 2016].

Nine Reasons Older Adults Are More Likely to Have Adverse Drug Reactions. Health Letter article. 2013. https://www.citizen.org/our-work/healthand-safety/nine-reasons-older-adults-are-morelikely-have-adverse-drug. [Accessed $5^{\text {th }}$ April 2019].

Palmer, M.E., Haller, C., McKinney, P.E., KleinSchwartz, W., Tschirgi, A., Smolinske, S.C., Woolf, A., Sprague, B.M., Ko, R., Everson, G., Nelson, L.S., Dodd-Butera, T., Bartlett, W.D., Landzberg, B.R. 2003. Adverse events associated with dietary supplements: an observational study. Lancet 361(9352): 101-6.

Relton, C., Cooper, K., Viksveen, P., Fibert, P., Thomas, K. 2017. Prevalence of homeopathy use by the general population worldwide: a systematic review. Homeopathy 106(2): 69-78.
Riedl, M.A, Casillas, A.M. 2003. Adverse drug reactions: types and treatment options. Am Fam Physician 68(9): 1781-90.

Schnyder, B., Pichler, W.J. 2009. Mechanisms of drug-induced allergy. Mayo Clin Proc 84(3): 268-72.

Schrijvers, R., Gilissen, L., Chiriac, A.M., Demoly, P. 2015. Pathogenesis and diagnosis of delayedtype drug hypersensitivity reactions, from bedside to bench and back. Clin Trans/ Allergy 5(1): 31.

Shih, C.C., Liao, C.C., Su, Y.S., Tsai, C.C., Lin, J.G. 2012. Gender differences in traditional Chinese medicine use among adults in Taiwan. PLOS One 7(4): e32540.

Sudershan, V., Siddiqua, S., Aruna, D., Manmohan, Ramesh, S., Nazia, Y. 2012. Cutaneous adverse drug reactions in a tertiary care hospital. Der Pharmacia Lettre 4(2): 408-13.

Talib, N.H., Leelavathi, M., Hamzah, Z. 2015. Common adverse cutaneous drug reaction patterns and the causative drugs in Malaysia. South African Family Practice 57(4): 227.-30

Thong, B.Y.H., Tan, T.C. 2011. Epidemiology and risk factors for drug allergy. Br J Clin Pharmacol 71(5): 684-700.

Zeng, Z.P., Jiang, J.G. 2010. Analysis of the adverse reactions induced by natural product-derived drugs. Br J Pharmacol 159(7): 1374-91.

Zhang, Y., Leach, M.J., Hall, H., Sundberg, T., Ward, L., Sibbritt, D., Adams, J. 2015. Differences between male and female consumers of complementary and alternative medicine in a National US Population: A Secondary Analysis of 2012 NIHS Data. Evid Based Complement Alternat Med 2015; 1-10

Received: 14 Sept 2018

Accepted: 30 April 2019 